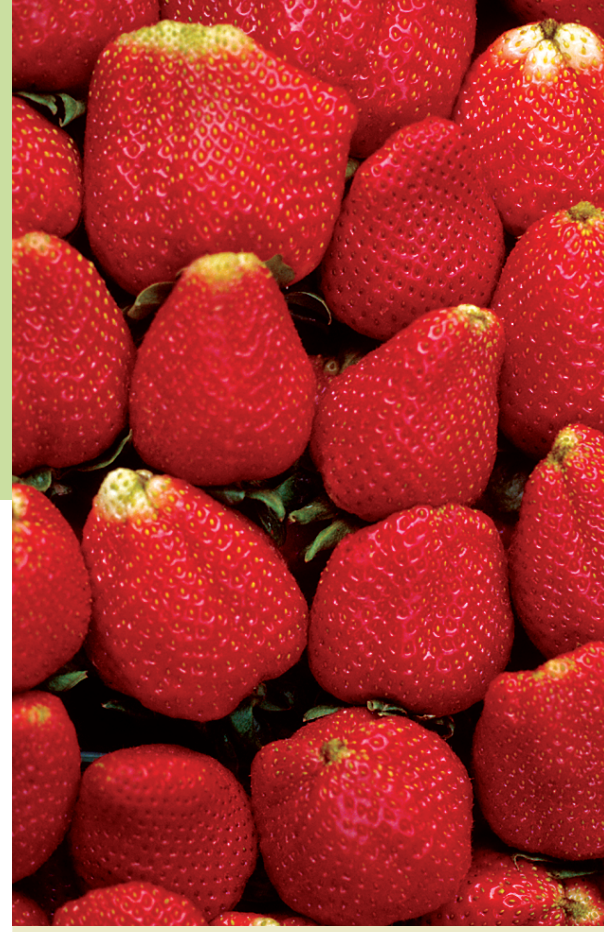

Blaine Hanson

Warren Bendixen

$\nabla$

About 4,000 acres of strawberries are grown in the Santa Maria Valley using drip irrigation. In order to help growers irrigate more effectively, we conducted studies to determine crop evapotranspiration; irrigation system performance; patterns and levels of soil salinity; soil moisture content around drip lines; and irrigation water quality. We also developed canopy growth curves. Results at 13 sampling locations showed maximum canopy coverage of less than $75 \%$. Crop evapotranspiration ranged from $\mathbf{1 2 . 2}$ inches to 15.6 inches. Irrigationsystem evaluations revealed that most of the distribution uniformities were greater than $80 \%$, considered acceptable. The electrical conductivities of the irrigation water ranged from 1 deciSiemens per meter $(d S / m)$ to $2.36 \mathrm{dS} / \mathrm{m}$; levels over $1 \mathrm{dS} / \mathrm{m}$ could result in yield reductions in strawberries. However, $79 \%$ of the samples had electrical conductivities equal to or less than $1.5 \mathrm{dS} / \mathrm{m}$. Levels of soil salinity in the vicinity of drip lines ranged from $1 \mathrm{dS} / \mathrm{m}$ to $3.5 \mathrm{dS} / \mathrm{m}$. This information can help growers calculate crop water needs and estimate irrigation set times.

\title{
Drip irrigation evaluated in Santa Maria Valley strawberries
}

$A^{b}$ bout 4,000 acres of strawberries are grown in the Santa Maria Valley, a small, triangular valley about 25 miles long and 10 miles wide located along the central California coast between San Luis Obispo and Santa Barbara. Strawberries in the valley are irrigated solely by drip irrigation. As is often the case in California, the urban sector competes with agriculture for water in the valley, generating interest in reducing agricultural water use. Despite the use of drip irrigation, there is still uncertainty about the precise amount of irrigation water needed for strawberry production, including for leaching of salts and crop evapotranspiration (ET), as strawberries are sensitive to salinity and water stress.

Since 1995, we have conducted studies on drip irrigation of strawberries in the Santa Maria Valley. In order to help strawberry growers irrigate more effectively, these studies included estimating crop evapotranspiration (ET, the amount of water evaporated from plants and soil), assessing irrigation water and soil quality, evaluating dripirrigation systems and determining patterns of salt and water around drip lines.

The Santa Maria Valley's climate is cool, with summer morning fog and moderate wind in the afternoon. The average annual rainfall is about 12 inches, most of which occurs between December and March. Little or no rainfall occurs during the summer and early fall. Soil textures consist of loamy sand and sandy loam throughout much of the valley with some clay loam near the coastline.

The sole source of irrigation water in the Santa Maria Valley is groundwater. Aquifers are recharged by percolation from the Santa Maria River and rainfall. The water quality is moderately saline with electrical conductivities (EC) generally ranging between 1 deciSiemens per meter $(\mathrm{dS} / \mathrm{m})$ and $1.5 \mathrm{dS} / \mathrm{m}$; its major chemical constituents are calcium, magnesium and sulfate.

Strawberry planting occurs near the end of October. Harvesting starts during the last week of February and generally continues until July. Initially, growers used 40-inch bed spacings

(22-inch bed width) with one drip line and two plant rows per bed. However, during the mid-1990s many switched to 64 -inch bed spacings (42-inch bed width) with two drip lines and four plant rows per bed. The advantages of wider beds include larger plant populations and higher raised beds, which aid in harvesting. Plastic mulch is used on all beds. Valleywide fresh-market yields were 31,311 pounds per acre in 1999 and 27,720 pounds per acre in 2000 , while the processed strawberry yields were 27,060 pounds per acre in 1999 and 35,520 pounds per acre in 2000 (Santa Barbara County Agriculture Commissioner's Report 2000).

\section{Glossary}

DAP: days after planting

DOY: day of year

dS/m: deciSiemens per meter (an indicator of salinity)

DU: distribution uniformity

EC: electrical conductivity

$\mathrm{EC}_{\mathrm{e}}$ : EC of saturated soil extracts

$E_{c}$ : crop evapotranspiration

ET: $_{\text {: }}$ reference crop evapotranspiration

$\mathbf{K}_{\mathbf{c}}$ : crop coefficient 

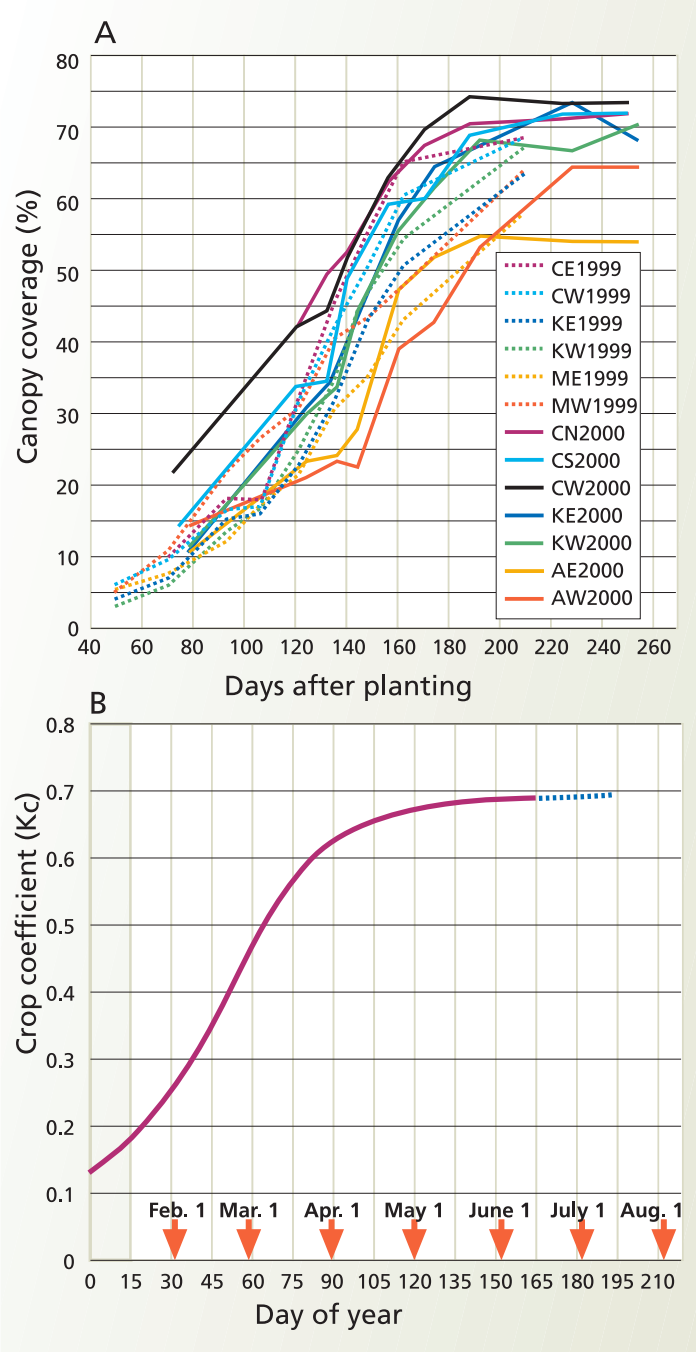

Fig. 1. (A) Canopy coverage versus days after planting at 13 locations and (B) average crop coefficients versus day of year for the Santa Maria Valley. Dotted line indicates uncertainty in data due to plant aging and damage.

rigation water samples were obtained at 34 locations and analyzed for EC and concentrations of soluble salts.

\section{Canopy coverage, ET, applied water}

We found considerable variability in canopy coverage among the sites (fig. 1A). The rapid canopy-growth stage generally started between 50 and 75 DAP and continued up to about 160 DAP, after which the growth rate decreased. The sites had different growth curves with maximum canopy coverages at several locations between $70 \%$ and $75 \%$. At these locations, canopy coverage based on the bed width (about 44 inches) plus canopy overhang was about $98 \%$ to $99 \%$, indicating that a $70 \%$ to $75 \%$ canopy coverage based on the

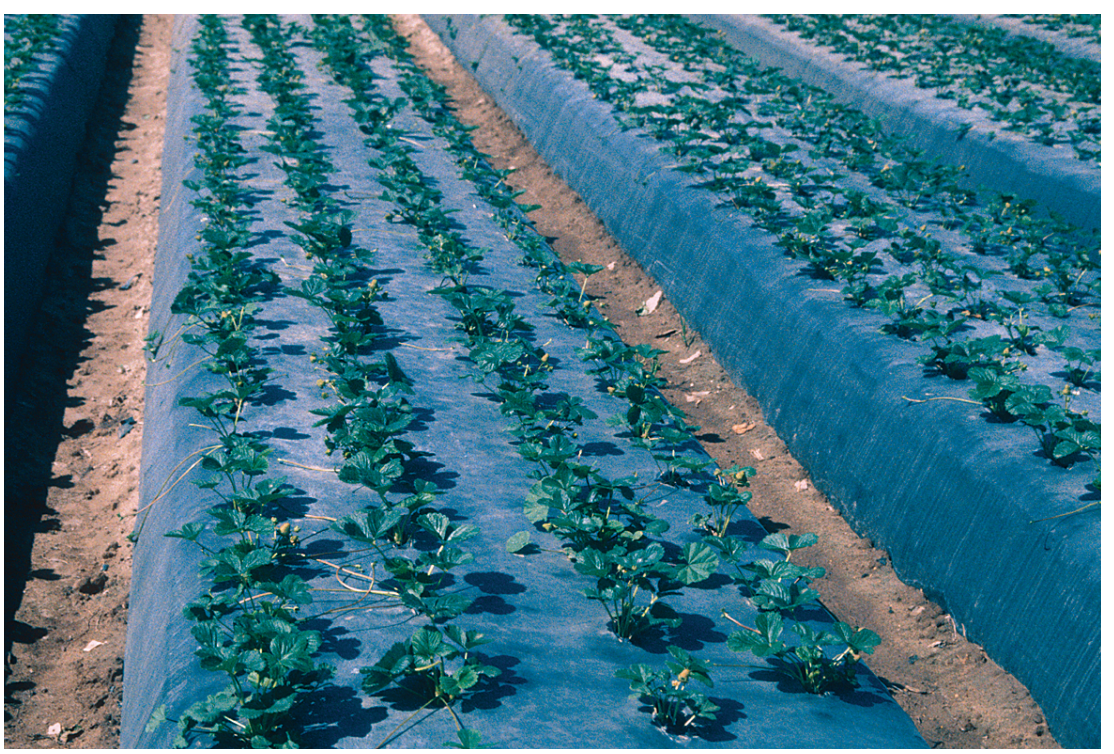

The authors determined crop evapotranspiration, patterns of soil salinity, soil moisture content, irrigation water quality and other irrigation variables. They also estimated canopy coverage, the percentage of soil area shaded by the plant's leaves at midday. Above, young strawberries are grown in black plastic mulch.

bed spacing (64 inches) is the maximum possible. Maximum coverages were between $60 \%$ and $75 \%$ except at AE2000 (54\%), for unclear reasons.

Crop coefficients expressed as a function of canopy coverage are considered more universal than those expressed on a time basis. However, growers are not likely to use crop coefficients based on canopy coverage because it is difficult and time consuming to estimate canopy coverage. Growers are more likely to use crop coefficients expressed on a time basis, such as day of year (DOY) or DAP. Therefore, we developed time-based crop coefficients using the canopy growth curves of locations with the highest maximum canopy coverages, on the assumption that maximum yields occur with maximum canopy growth. We found smaller maximum canopy coverages at some sites, but did not use them to develop crop coefficients because the impacts on yield were unknown.

The crop coefficient increased rapidly with DOY up to about the first of April (fig. 1B). Thereafter, crop coefficients increased more gradually to the maximum coefficient of about 0.69 . However, near the end of the crop season, growers experienced reduced crop ET due to plant aging, and a decrease in plant height and plant damage due to harvesting. The crop coefficient curve on figure $1 \mathrm{~B}$ is shown as a dashed line during the late growth stage, indicating that crop coefficients may need to be decreased to reflect reduced ET.

The daily crop ET for site CN2000, for example (fig. 2), was less than 0.05 inches per day up to about 135 DAP. After 135 DAP, both crop ET and reference crop ET increased with maximum values between about 170 DAP and $230 \mathrm{DAP}$, then decreased. Maximum daily crop ET rates were about 0.14 inches per day.

The calculated season crop ET was determined from Jan. 1 to about mid-July for all locations (table 1). Seasonal ET ranged from 12.4 inches to 15.6 inches in 1999 and from 12.2 inches to 15.5 inches in 2000. As expected, locations with higher seasonal crop ET also had the highest canopy coverages. The AE2000 site, which had the smallest seasonal $\mathrm{ET}_{\mathbf{c}^{\prime}}$ also had the smallest maximum coverage, about $54 \%$. It would have been useful to compare

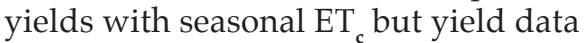
was unavailable.

Cumulative applied water exceeded seasonal ET at all 2000 sites except KE2000 and KW2000 (table 1). At these sites, the grower intentionally used deficit irrigation to reduce excessive canopy growth, which he said was a problem 


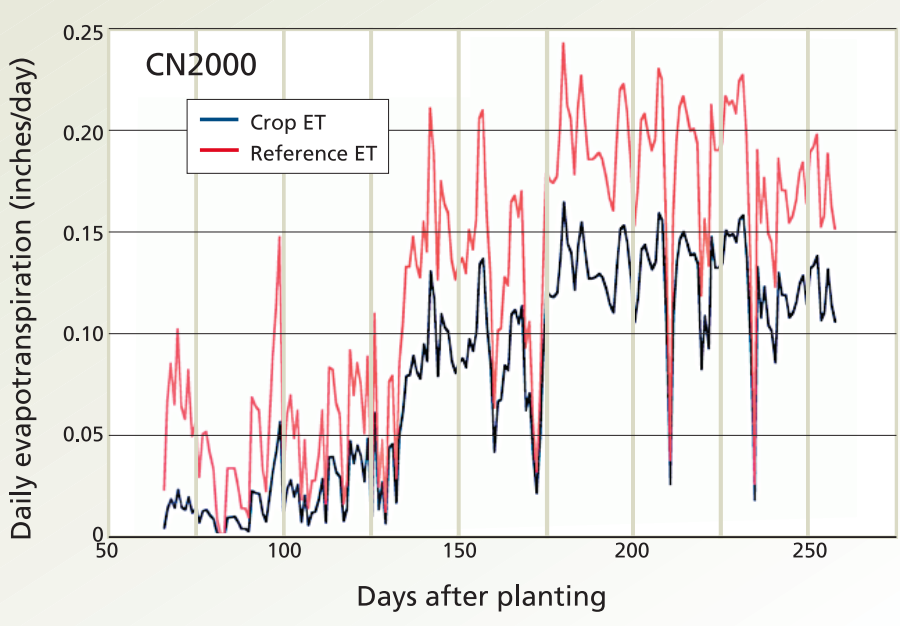

Fig. 2. Crop ET and reference crop ET for site CN2000.

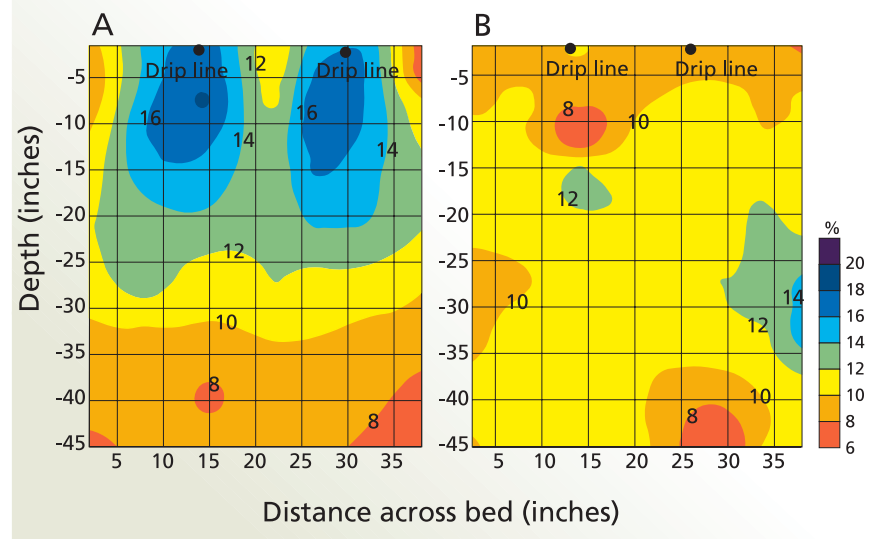

Fig. 3. Pattern of gravimetric soil moisture content (\%) around the drip lines (A) just after an irrigation and (B) after several days of drying. Contour lines show equal soil moisture content. The color scale shows soil moisture content associated with colors between the contour lines. with his variety. Nonetheless, maximum canopy coverage was nearly $70 \%$. Data on applied water was not available in 1999 because despite the use of filters, silt in the irrigation water caused the flow meters to malfunction, jamming the metering mechanism.

\section{Drip system performance}

With one exception, distribution uniformities (DU) of the drip-irrigation systems ranged from $81 \%$ to $96 \%$ (table 2). These high values reflect the short drip lines, which ranged from 190 feet to 350 feet, and the new drip tape used

TABLE 1. Cumulative crop evapotranspiration (ET), applied water and leaching fraction for strawberry in Santa Maria Valley, Jan. 1-July 15

\begin{tabular}{lccc}
\hline \hline Site & Crop ET & $\begin{array}{c}\text { Applied } \\
\text { water }\end{array}$ & $\begin{array}{c}\text { Leaching } \\
\text { fraction }\end{array}$ \\
\hline CE1999 & $\ldots$ inches . . . & $\%$ \\
CW1999 & 15.6 & $*$ & $*$ \\
KE1999 & 15.6 & $*$ & $*$ \\
KW1999 & 12.9 & $*$ & $*$ \\
ME1999 & 12.4 & $*$ & $*$ \\
MW1999 & 12.5 & $*$ & $*$ \\
CN2000 & 15.5 & 14.5 & 0 \\
CS2000 & 15.4 & 18.9 & 18.5 \\
CW2000 & 15.5 & 21.6 & 28.2 \\
KE2000 & 15.1 & 13.0 & 0 \\
KW2000 & 15.1 & 10.4 & 0 \\
AE2000 & 12.2 & 14.6 & 16.4 \\
AW2000 & 12.8 & 16.1 & 20.5 \\
\hline
\end{tabular}

* Data not obtained because of flow meter malfunction. each year. The average drip-line discharge rates ranged from 0.5 gallons per minute [gpm] per 100 feet to $0.75 \mathrm{gpm}$ per 100 feet due to high-flow emitters and spacing of emitters on the drip tape. Interestingly, the drip system with the lowest DU also had the lowest drip-line discharge rate.

DU largely depends on pressure variations along drip lines and manifolds, and whether any emitters are clogged. An analysis of variance was conducted to determine the statistical significance of differences in discharge rates between adjacent emitters, and along and between drip lines. For most locations, the differences were statistically insignificant. However, at site CT2, differences between drip lines and adjacent emitters were highly significant, causing an unacceptable DU of $60 \%$. Although we found several significant differences between drip lines and emitters among sites, they appeared to have little effect on the DUs of these systems.

Soil moisture content. Patterns of soil moisture around the drip line at one location in a sandy loam soil showed a vertical elongation of wetting under the drip tape typical in sandy soils with drip irrigation (fig. 3A). Most of the lateral wetting occurred over an interval of about 6 inches from the drip line. Similar behavior was found at most other locations. However, at one location considerable drying occurred throughout the soil profile, particularly at depths less than about 12 inches (fig. 3B). At this site, the interval between irrigations may have been too long. This information can help growers understand how water is distributed around the drip lines and the levels of soil moisture found under drip irrigation.

Salinity. Salt in irrigation water is the main source of soil salinity, which is detrimental to salt-sensitive crops such as strawberry. Analyses of the irrigation water revealed an average EC of $1.43 \mathrm{dS} / \mathrm{m}$ (data not shown), but ranging from $1 \mathrm{dS} / \mathrm{m}$ to $2.36 \mathrm{dS} / \mathrm{m}$. The higher values occurred at locations 3 miles to 5 miles west of the city of Santa Maria, near a waste treatment plant. However, the EC of $79 \%$ of the water samples was equal to or less than $1.5 \mathrm{dS} / \mathrm{m}$. These waters were classified as a calcium/magnesium/sulfate water. Concentrations of calcium were slightly greater than magnesium, while sulfate dominated the anion concentrations. The relationship between total dissolved salts (TDS) in parts per million and the water EC in dS/ $\mathrm{m}$ was:

$$
\text { TDS }(\mathrm{ppm})=742 \times \mathrm{EC}(\mathrm{dS} / \mathrm{m})(1)
$$

The coefficient of determination was 0.97 . This equation differs from that developed by the U.S. Salinity Laboratory, which used a generic constant of 640 .

We found that soil salinity was least below the drip lines and de- 


\begin{tabular}{|c|c|c|c|}
\hline Site & $\begin{array}{l}\text { Lateral } \\
\text { length }\end{array}$ & $\begin{array}{l}\text { Emission } \\
\text { uniformity }\end{array}$ & $\begin{array}{c}\text { Average } \\
\text { drip-line } \\
\text { discharge } \\
\text { rate }\end{array}$ \\
\hline & feet & $\%$ & $g p m / 100 \mathrm{ft}$ \\
\hline CG1 & 350 & 88 & - \\
\hline CT & 300 & 80 & - \\
\hline CG2 & 287 & 96 & 0.71 \\
\hline GGC & 190 & 94 & 0.34 \\
\hline BP & 240 & 94 & - \\
\hline SL & 300 & 84 & 0.75 \\
\hline RR & 295 & 90 & 0.57 \\
\hline BSM & 300 & 81 & 0.63 \\
\hline $\mathrm{CT} 2$ & - & 60 & 0.50 \\
\hline
\end{tabular}
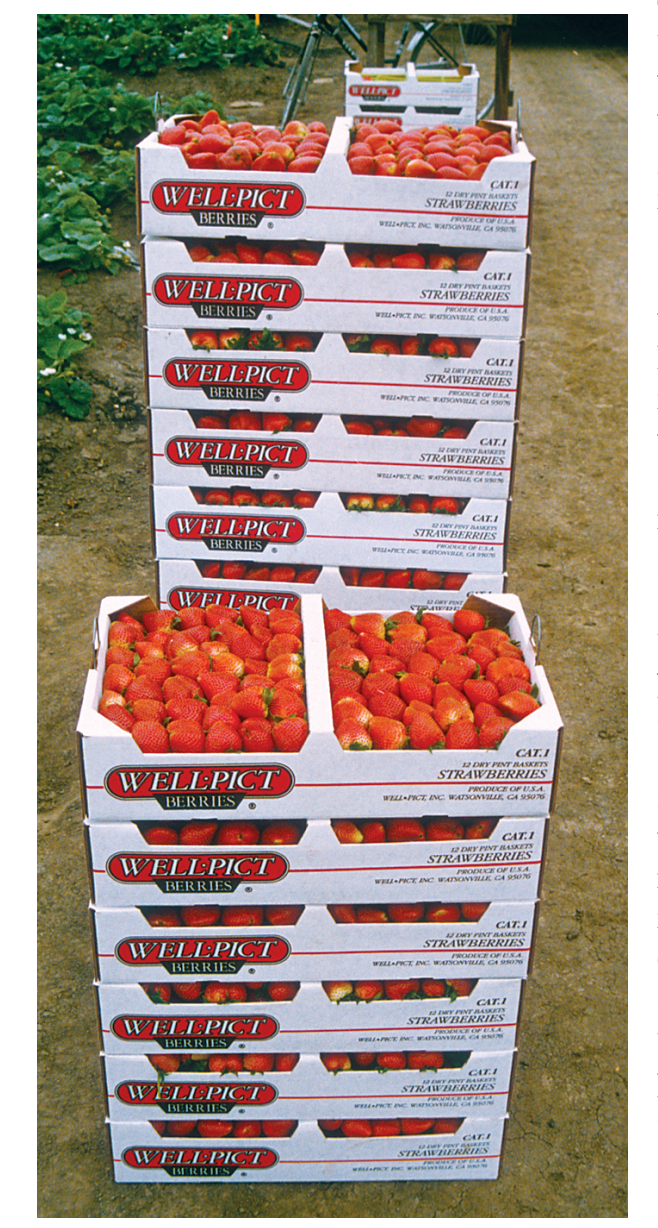

Levels of soil salinity around the drip lines were relatively high, indicating possible impacts on yields.

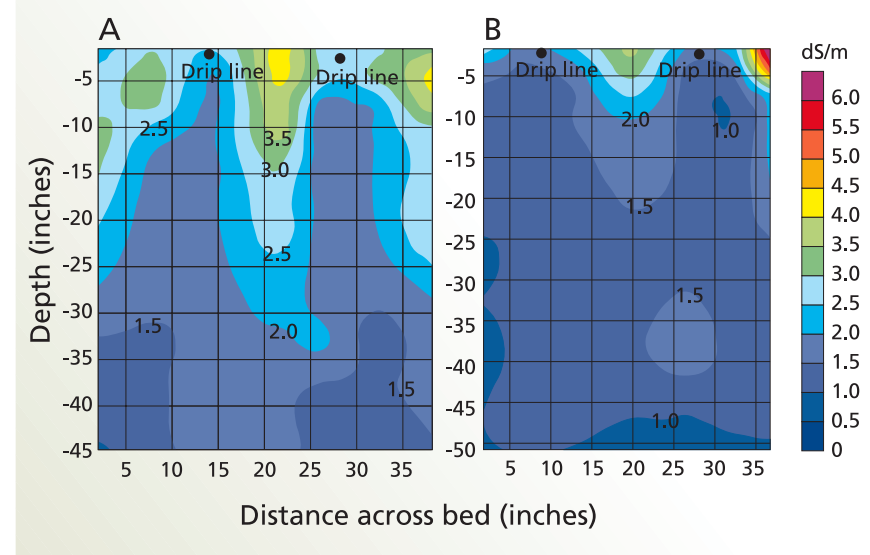

Fig. 4. Pattern of soil salinity, expressed as the EC (dS/m) of saturated extracts, around drip lines for sites with relatively (A) low and (B) high leaching. Contour lines show equal EC $(\mathrm{dS} / \mathrm{m})$. The color scale shows $\mathrm{EC}_{\mathrm{e}}$ associated with colors between contour lines.

creased with depth, indicating leaching beneath the drip lines (fig. 4A, B). Maximum levels of soil salinity occurred midway between the drip lines and near the bed edges. $\mathrm{EC}_{\mathrm{e}}$ values throughout the soil profile were smaller in figure $4 \mathrm{~B}$ than $4 \mathrm{~A}$, suggesting that more leaching occurred at the figure $4 \mathrm{~B}$ site. EC values for the irrigation water were similar for both sites. In general, $\mathrm{EC}_{\mathrm{e}}$ values near the drip lines ranged from $1 \mathrm{dS} / \mathrm{m}$ to $3.5 \mathrm{dS} / \mathrm{m}$ for depths less than about 12 inches (the approximate root depth). Some $\mathrm{EC}_{\mathrm{e}}$ values near the drip lines were similar to EC of the irrigation water. This reflects the high-frequency irrigation used in drip irrigation and method of determining $\mathrm{EC}_{\mathrm{e}^{\prime}}$ which involves adding distilled water to dry soil until a saturated paste forms.

At locations where soil salinity near the drip lines exceeds a threshold value, yield reductions could occur. In this case, the threshold value of about $1 \mathrm{dS} / \mathrm{m}$ is the maximum root-zone salinity that can occur in strawberries without yield reductions. Under drip irrigation, it is difficult to define the root zone around the drip line, but most of the roots are likely to occur near the drip line. Salinity measurements near the drip line provide information on the potential salinity hazard as related to crop yield.

Based on estimates of crop ET and applied water measurements, leaching fractions ranged from $0 \%$ to $28.2 \%$ for the 2000 sites (table 1). These values reflect a fieldwide leaching fraction (leaching is the only way to control salt in the root zone). However, actual leaching fractions vary greatly with distance from drip lines. The relatively low $\mathrm{EC}_{\mathrm{e}}$ levels found below the drip lines indicate that leaching is greater than at other horizontal distances from the drip line (fig. 4B).

Irrigation water management. Water management in drip-irrigation systems involves determining an irrigation frequency and the amount of water to apply. The irrigation frequency should be small enough to prevent excessive soil moisture depletion near the drip line, which could reduce crop yield. Intervals between irrigations were determined from the soil moisture data and ranged from 1 day to as much as

TABLE 3. Historical reference crop evapotranspiration $\left(E_{0}\right) *$, crop coefficient $\left(K_{c}\right)$ and crop ET of strawberry (ET) for strawberry in Santa Maria Valley

\begin{tabular}{|c|c|c|c|}
\hline & $\mathrm{ET}_{0}$ & $\mathbf{K}_{c}$ & $\mathrm{ET}_{c}$ \\
\hline & inches/da & & \\
\hline \multicolumn{4}{|l|}{ inches/day } \\
\hline Jan $1-15$ & 0.06 & 0.15 & 0.009 \\
\hline Jan 16-31 & 0.07 & 0.21 & 0.015 \\
\hline Feb 1-15 & 0.18 & 0.30 & 0.024 \\
\hline Feb 16-28 & 0.10 & 0.41 & 0.04 \\
\hline Mar 1-15 & 0.11 & 0.52 & 0.06 \\
\hline Mar 16-31 & 0.14 & 0.60 & 0.08 \\
\hline Apr 1-15 & 0.17 & 0.64 & 0.11 \\
\hline Apr 16-30 & 0.18 & 0.66 & 0.12 \\
\hline May 1-15 & 0.19 & 0.68 & 0.13 \\
\hline May 16-31 & 0.19 & 0.69 & 0.13 \\
\hline Jun 1-15 & 0.20 & 0.69 & 0.14 \\
\hline Jun 16-30 & 0.20 & 0.69 & 0.14 \\
\hline Jul 1-15 & 0.19 & 0.69 & 0.13 \\
\hline Jul 16-31 & 0.18 & 0.70 & 0.13 \\
\hline
\end{tabular}




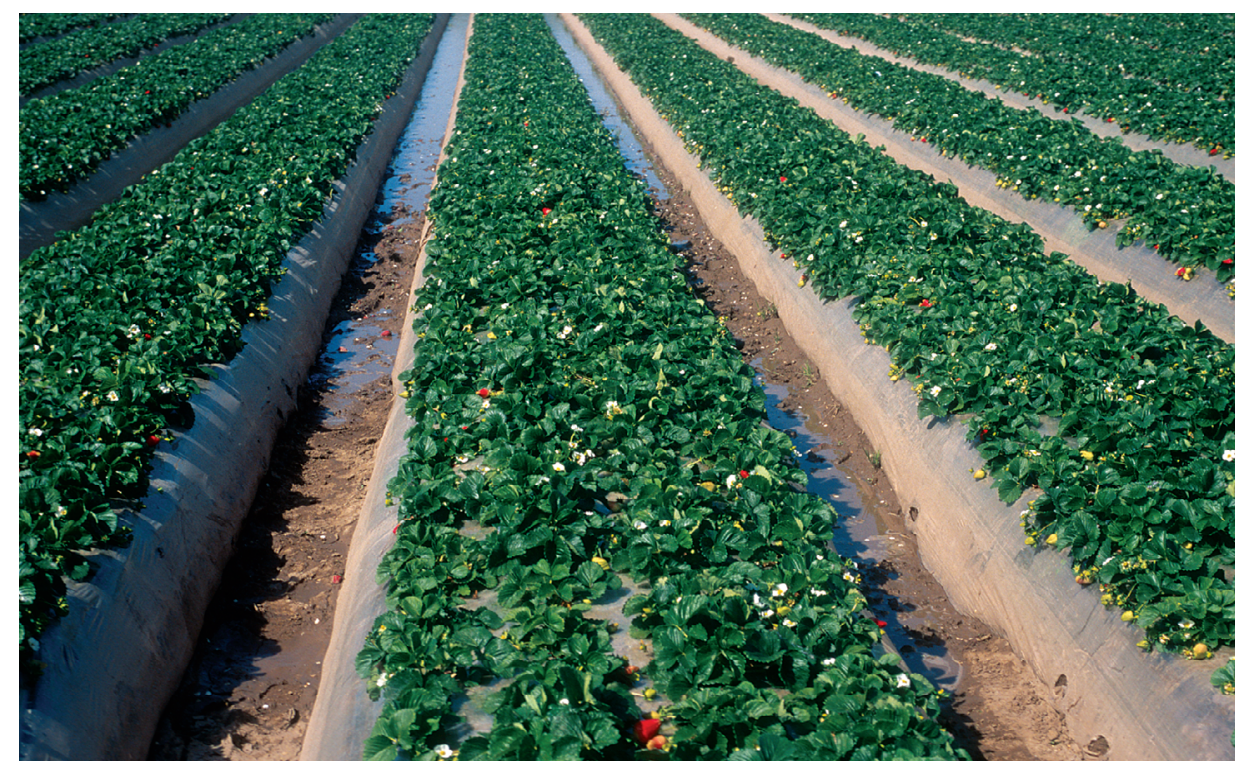

10 days. For the 2000 sites, the average interval between irrigations was

3 days to 4 days.

The amount of water applied during an irrigation should equal the crop ET between irrigations plus that needed for inefficiencies in the irrigation system. The irrigation set time, or duration of the irrigation, depends on the amount of applied water and the application rate of the irrigation system. We developed a simple equation for estimating the irrigation set time using values of historical reference crop ET (table 3) in the Santa Maria Valley (except near Guadalupe). In this equation, $I$ is days between irrigations, $q$ is drip-line discharge rate (gpm/100 feet), and Ts is the irrigation set time (hours). An irrigation efficiency of $85 \%$ was assumed for this calculation (based on DU data):

$$
\mathrm{Ts}_{\mathrm{s}}=6.52 \times \mathrm{ET}_{\mathrm{c}} \times I / q(2) .
$$

For example, to calculate the irrigation set time needed during the first part of June (daily $\mathrm{ET}_{\mathrm{c}}=0.14$ inches per day) for an irrigation interval of 3 days and drip-line discharge rate of $0.6 \mathrm{gpm} / 100$ feet: $T s=6.52 \times 0.14 \times$ $3 / 0.6=4.6$ hours.

\section{Irrigating in Santa Maria Valley}

Canopy coverage measurements made over a 2-year period revealed a maximum possible coverage between $70 \%$ and $75 \%$, achieved at most locations. Rapid canopy growth generally occurred up to about 160 DAP. The crop coefficient curve (fig. 1B) showed crop coefficients increasing rapidly with time to about April 1. We found a maximum coefficient of about 0.69 . This time-based relationship is unique to the Santa Maria Valley, or areas with similar climates. Areas with considerably different climates may have different canopy growth curves.

An analysis of nearly 1,000 evaluations of irrigation systems (Hanson et al. 1995) found that properly designed and maintained microirrigations systems should have DUs of at least $80 \%$, which this study showed to be feasible and practical. The drip systems used for strawberry production generally meet this minimum standard (table 2).

The effect of $\mathrm{EC}_{\mathrm{e}}$ values found at our study locations on crop yield is unclear. Salt tolerance of some crops is greater in cool, humid climates than in hot, dry climates. Also, under the gypsiferous water and soil conditions of the Santa Maria Valley, threshold salinity values may be $1 \mathrm{dS} / \mathrm{m}$ to $3 \mathrm{dS} / \mathrm{m}$ higher than the normal threshold value at field capacity (Maas 1990). These possibilities suggest that the levels of soil salinity in the vicinity of the drip lines may not significantly affect crop yield.

In our study, applied water generally exceeded crop ET. For those locations with maximum canopy growth, the amount of applied water appears to be sufficient to meet both crop ET and leaching needed for maximum growth. However, relationships between yield and applied water are needed to determine the effect of the irrigation management on crop yield.
The maximum canopy coverage for strawberries in Santa Maria Valley was $70 \%$ to $75 \%$, with rapid growth until about 160 days after planting.

The information developed in these studies allows strawberry growers to calculate crop water use between irrigations and to estimate the amount of time needed to supply the desired water. These studies also show that levels of soil salinity under drip irrigation can become relatively high, raising the possibility of crop yield reductions.

B. Hanson is Irrigation and Drainage Specialist, Department of Land, Air and Water Resources, UC Davis; and W. Bendixen is Farm Advisor, UC Cooperative Extension, Santa Barbara County.

\section{References}

Grattan SR, Bowers W, Dong A, et al. 1998. New crop coefficients estimate water use of vegetables, row crops. Cal Ag 52(1):16-21.

Hanson B, Bowers W, Davidoff B, et al. 1995. Field performance of microirrigation systems. In: Microirrigation for a Changing World, Proc Fifth Int Microirrigation Congress, Am Soc Ag Engineers, Orlando, FL, April 2-6, 1995. p 769-74.

Hanson BR, Kaita K. 1999. Historical reference crop ET reliable for irrigation scheduling during summer. Cal Ag 53(4):32-6.

Hsiao TC, Henderson DW. 1985. Improvement of crop coefficients for evapotranspiration. In: California Irrigation Management Information System Final Report, June 1985. California Department of Water Resources.

Maas EV. 1990. Crop salt tolerance. In: Tanji KK (ed.). Agricultural Salinity Assessment and Management. ASCE Manuals and Reports on Engineering Practice No 71. American Society of Civil Engineers. 619 p. Santa Barbara County Agriculture Commissioner's Report. 2000. Santa Maria Valley. 